\title{
Türkiye’de Yönetim Muhasebesiyle İlgili Hazırlanan Tezlerin Bibliyometrik Analiz Yöntemiyle İncelenmesi
}

\author{
A Resarch On The Theses Prepared On The Management Accountıng in Turkey by The Bıbliometric Analysis \\ Method
}

\author{
Abdurrahman Gümrah*(D) \\ ${ }^{1}$ Department of Vocational School of Social Sciences, Selguk University, Konya, Turkey
}

\begin{abstract}
Received: 07.06 .2020
Accepted: 29.09.2020

This article was checked by intihal.net

ISSN: $2149-8598$

$\ddot{O} z$

Bu çalışmanın amacı Türkiye'de yönetim muhasebesi konusunda hazırlanmış olan lisansüstü tezlerin hazırlandığı üniversite, yıl, enstitü, anabilim dalı, danışmanlık yapan öğretim üyelerinin unvanları ve yüksek lisans tezi- doktora tezi olarak ayırımının belirlenmesi oluşturmaktadır. Çalışmada nitel araştırma yöntemlerinden olan Bibliyometri tekniği kullanılmış olup Yüksek Öğretim Kurulu Başkanlığı (YÖK) Ulusal Tez merkezi sayfasında tarama terimi olarak "Yönetim Muhasebesi”, aranacak alan, izin durumu ve tez türü kısımları ise “Tümü” şeklinde işaretlenerek 2020 Yılı Nisan ayında tarama işlemi gerçekleştirilmiştir. Tarama sonrası 172 adet lisansüstü tezin YÖK Ulusal Tez Merkezine kayıtlı olduğu tespit edilmiştir. Söz konusu tezlerden 9 tanesine yazarın erişime izin vermemesi, tezin çok eski tarihli olması ve YÖK tez merkezinde elektronik kaydının olmaması gibi sebeplerden ötürü erişim sağlanamamıştır. Böylelikle araştırma kapsamında 163 adet lisansüstü tez incelenmiştir. İlk tez 1985 yılında hazırlanırken, 2019 yılında 19 tezle en yüksek sayıya ulaşılmıştır. Yine 1993 yılında yazılmış lisansüstü tez bulunmamaktadır. Yönetim muhasebesi konusunda 19 tezle en fazla tezin Marmara Üniversitesi bünyesinde hazırlandığı, tez türü olarak en fazla yüksek lisans düzeyinde tezin hazırlandığı, söz konusu tezlere en çok Prof. Dr. unvanlı öğretim üyelerinin danışmanlık yaptığı çalışma sonucunda tespit edilen bulgulardır. Özellikle yönetim muhasebesi konusunda lisansüstü tez hazırlamak isteyen araştırmacıların Marmara Üniversitesi bünyesinde alanında uzman öğretim üyeleriyle çalışabilecekleri düşünülmektedir. Ayrıca Türkiye' de son yıllarda üniversite sayısındaki artış göz önünde bulundurulduğunda diğer üniversitelerinde yönetim muhasebesi konusuna önem vermeleri tavsiye edilmektedir.
\end{abstract}

Anahtar Kelimeler: Yönetim Muhasebesi, Bibliyometrik Analiz, Muhasebe

\section{Abstract}

The purpose of this study is to break down the postgraduate theses prepared on accounting management in Turkey in terms of university, year, institute, department, titles of advisor faculty members and whether the theses are master's thesis or PhD thesis. In this study, bibliometric analysis (bibliometry) technique, a qualitative research method, was used, and the screening process was performed in April, 2020, on the website of Higher Education Council (YOK) National Thesis Center by selecting "Management Accounting" as the search term and marking the permission status and thesis type fields as "All". As a result of the search, it was found that 172 postgraduate theses are registered in the YÖK National Thesis Center. We could not access to 9 of these theses, due to reasons such as author's not allowing access, the thesis being too old and not having an electronic record in the YÖK's thesis center. Therefore, 163 postgraduate theses were examined within the scope of the study. The highest number of theses was found in 2019 with 19 theses, while the first one was written in 1985. Also, no postgraduate thesis was written in 1993 . The findings are that most of the theses on management accounting were prepared by Marmara University with 19 theses; in terms of type of thesis, most of the theses were master's theses; and the faculty members with the title of "Prof. Dr." mostly advised such theses. It is considered that the researchers who want to prepare a postgraduate thesis, especially in the field of management accounting, are able to work with specialized academicians at Marmara University. In addition, considering the increase in the number of universities in Turkey in recent years, it is recommended that other universities should pay importance to the subject of management accounting.

Keywords: Management Accounting, Bibliometric Analysis, Accounting

Gümrah, A. (2020). “Türkiye'de Yönetim Muhasebesiyle İlgili Hazırlanan Tezlerin Bibliyometrik Analiz Yöntemiyle İncelenmesi”, Journal of Academic Value Studies, 6(3) 244-253 (http://dx.doi.org/10.29228/javs.44081).

\footnotetext{
*E-mail address: agumrah@selcuk.edu.tr
} 


\section{Giriş}

Günümüz işletmelerinde yönetim fonksiyonu giderek artan bir öneme sahip olmaktadır. Son zaman-larda dünya genelinde görülen salgınlar finansal ve finansal olmayan kuruluşlarda yönetim kararlarının ne derece büyük öneme sahip olduğunu tekrar göstermiştir. Yöneticilerin karar alma sırasında geçmiş verileri, gelecekte gerçekleşmesi muhtemel olaylara yorumlaması olarak tanımlanan yönetim muha-sebesi de yöneticiler için oldukça büyük öneme sahiptir.

Yönetim muhasebesi alanında yapılan çalışmalar sadece muhasebe disipliniyle sınırlı kalmamaktadır. Zira hangi alanda faaliyet gösterirse göstersin tüm kuruluşların bir yönetimi bulunmakta ve karar alma mekanizmaları bu yönetim etrafında toplanmaktadır. Çalışmanın ilerleyen kısımlarında yapılan litera-tür araştırmasında da görüleceği üzere sağlıktan spor bilimlerine, fen bilimlerinden mühendislik bilim-lerine kadar birçok alanda yönetim muhasebesi kapsamında bilimsel çalışmalar yapılmaktadır. Bu bağ-lamda yönetim muhasebesi konusunda yapılan çalışmaların tüm bilim dalları açısından önem arz ettiği söylenebilir. Söz konusu önem doğrultusunda bu çalışmada yönetim muhasebesi konusunda Türki-ye'de hazırlanmış olan lisansüstü tezler bibliyometrik analiz yöntemiyle incelenmiştir.

Bibliyometrik analiz, araştırma konusuyla ilgili tarihsel eğilimi ve performansı ortaya koymaktadır (Huang ve Ho, 2011:276). Bibliyometri, bibliyografik materyalleri nicel olarak inceleyen temel bilimler arasında yer almaktadır. Bibliyometri mevcut bilgileri belirli bir bilimsel disiplin içerisinde düzenleye-rek alanla ilgili araştırma yapmayı planlayanlara sunduğu için oldukça faydalı bir araştırma yöntemi olarak karşımıza çıkmaktadır (Merigó ve Yang, 2017:71).

Bilimsel literatürün mevcut durumunu ortaya koymak adına bibliyometrik analiz yönteminden fayda-lanılmaktadır. Daha açık bir ifadeyle bibliyometrik analiz yöntemiyle yapılmış olan çalışmaların, ya-pıldığı bilimsel literatürün "büyük resmini ortaya koyduğu" yada "kuş bakışı" değerlendirme yapmak için en ideal yöntem olduğu kabul edilmektedir. Bu analiz yönteminde tüm mikro ve makro yayın mo-delleri matematiksel hesaplamalar yardımıyla nicel yönden değerlendirilmektedir. Bibliyometrik ana-liz yöntemi bilimsel yayınları ve bilgiyi analiz edebilmesinden ötürü literatürün takip edilmesini kolay-laştırdığı varsayımıyla özellikle 1980 sonrası yoğun ilgi görmüştür (Ercan, 2020:22).

Literatürde bibliyometrik analiz yöntemiyle farklı bilim disiplinlerde yapılmış çok sayıda araştırma yer almaktadır. Bibliyometrik analiz yöntemiyle yapılmış olan her bir çalışma, yapıldığı alanda gele-cekte yapılacak olan çalışmalara yol gösterici nitelik taşımaktadır. Zira bibliyometrik analiz yöntemiy-le yapılmış olan çalışmalar, araştırmacıların geçmişi bir düzen dahilinde görebilmelerine imkan tanı-maktadır. Bu bağlamda çalışmanın amacı, Türkiye'deki üniversitelerde yönetim muhasebesi alanında yapılmış lisansüstü tez çalışmalarını bibliyometrik özellikler çerçevesinde incelemektir. Çalışmada nitel araştırma yöntemlerinden olarak bibliyometrik analiz yöntemi doküman inceleme tekniği yar-dımıyla kullanılmıştır. Çalışmada Türkiye'de yönetim muhasebesi alanında hazırlanmış lisansüstü tez-lerin belirli özellikleri incelerek yönetim muhasebesi alanına ilişkin veriler elde edilmiştir. Söz konusu veriler Yüksek Öğretim Kurulu Ulusal Tez Merkezi'nin web sayfası üzerinden "yönetim muhasebesi” anahtar kelimesi taratılarak elde edilmiştir. Çalışmada ulaşılan lisansüstü tezler tezin hazırlandığı yıl, üniversite, enstitü, anabilim dalı, türü ve danışman unvanı kıstasları doğrultusunda incelenmiştir.

Çalışmada ilk olarak farklı bilim disiplinlerinde ve muhasebe biliminde bibliyometrik analiz yöntemiy-le yapılmış olan çalışmaların incelendiği literatür araştırmasına yer verilmiştir. Sonrasında çalışmanın önemi, amacı, kapsamı, yöntemi ve sınırlılıklarına değinilmiştir. Çalışmanın üçüncü kısmında yapılan analizler sonucu elde edilen bulgular yer almaktadır. Çalışmanın son kısmı olan sonuç kısmında ise ulaşılan bulgular analiz edilerek yorumlanmış ve gelecek çalışmalara önerilerde bulunulmuştur.

\section{Literatür Taraması}

Çalışma kapsamında yapılan literatür taraması iki aşamadan oluşmaktadır. İlk aşamada literatürde lisansüstü tez çalışmalarını konu edinen araştırmalar, ikinci aşamada ise "muhasebe" konusunda yapılmış bibliyometrik araştırmalar incelenmiştir.

Literatürde, lisansüstü tez çalışmalarını konu edinmiş çok sayıda araştırma yer almaktadır. Söz konusu araştırmalardan bir kısmı aşağıda yer almaktadır.

Armutlu ve Arı (2010) çalışmalarında lisansüstü tezlerde yönetim modalarına gösterilen ilgiyi tespit etmeye çalışmışlardır. Çalışma kapsamında 1986-2008 yılları arasında toplam kalite yönetimi, kalite çemberleri, değişim 
mühendisliği, kıyaslama, personel güçlendirme ve altı sigma konularında hazırlanmış 520 tez bibliyometrik analiz yöntemiyle incelenmiştir. Araştırma sonucunda en fazla ve uzun süreli ilgi gören yönetim modasının toplam kalite yönetimi olduğu tespit edilmiştir.

Becerikli (2013) çalışmasında sağlık iletişimi üzerine hazırlanmış olan lisansüstü tezleri incelemiştir. Çalışma kapsamında 16 adet tez incelenmiştir. Çalışmada kapsam dahiline alınan tezler çeşitli kıstaslar doğrultusunda bibliyometrik analiz yöntemiyle incelenmiştir.

Aydın (2017) çalışmasında yiyecek içecek işletmeciliği alanında yazılıış lisansüstü tezleri incelemiştir. Çalışma kapsamında 1988-2013 yılları arasında hazırlanmış 179 adet tez incelenmiştir. Çalışmada incelenen tezler, ilgili alanda en çok tercih edilen konular, araştırma türü, araştırma yaklaşımı, araştırma alanı, araştırma yürütülen anabilim dalları, üniversiteler, araştırmaya danışmanlık yapan kişiler vb. şeklinde sınıflandırmalarla bibliyometrik analize tabi tutulmuştur.

Beşel (2017) çalışmasında maliye alanında yazılmış lisansüstü tezleri bibliyometrik analiz yöntemiyle incelemiştir. Çalışma kapsamında 2003-2017 yılları arası hazırlanmış 1714 adet tez doküman inceleme tekniğiyle analiz edilmiştir. Çalışmada incelenen tezler çok farklı değişkenler açısından incelenmiştir.

Akkaşoğlu ve diğ. (2019) çalışmalarında tarım turizmine yönelik hazırlanan lisansüstü tezleri bibliyometrik açıdan incelemişlerdir. Çalışmada 19 lisansüstü tez çalışması, tezlerin dağılımları, türleri, yılları, üniversiteleri, enstitüleri, anabilim dalları, danışman unvanları, sayfa sayıları, kaynakça sayıları ile türleri, anahtar kelimeleri ve yöntem içerikleri açısından incelenmiştir. (Ayaz ve Türkmen, 2018) çalışmalarında yöresel yiyecekleri konu alan lisansüstü tezleri bibliyometrik analiz yöntemiyle incelemişlerdir. Çalışma kapsamında 1990-2017 yılları arasında hazırlanmış 45 adet lisansüstü tez incelenmiştir. Söz konusu inceleme yıl, üniversite, ana bilim dalı, yazım dili, tez türü, çalışma konusu, anahtar kelimeler ve araştırma yöntemi değişkenleri bakımından yapılmıştır.

Yukarıda yer alan literatür özetinden de anlaşılacağı üzere farklı bilim dallarını konu edinmiş lisansüstü tezleri bibliyometrik olarak inceleyen çok sayıda çalışma bulunmaktadır. Yapılan çalışmalar tek bir bilim dalıyla sınırlı kalmamış, spordan sağlığa, tarihten turizme kadar geniş bir alana yayılmıştır. Çalışmada ikinci literatür araştırması muhasebe alanında yapılmış çalışmalara yönelik olarak gerçekleştirilmiştir. Aşağıda muhasebe alanında bibliyometrik analiz yöntemiyle yapılmış çalışmaların bir kısmın yer verilmiştir.

Hotamışlı ve Erem (2014) çalışmalarında Muhasebe ve Finansman Dergisi'nde 2005-2013 yılları arasında basılmış makaleleri bibliyometrik analiz yöntemiyle incelemişlerdir. Çalışma kapsamında 562 adet makale incelenmiştir. Araştırma sonucunda incelenen makalelerde finansal performans, kamu ekonomisi ve finansal piyasalar konularına ağıllık verildiği, en fazla yayın yapan kurumların sırasıyla Marmara, Trakya ve İstanbul Üniversiteleri olduğu ve atıf yapılan kaynaklar olarak da sırasıyla dergiler, diğer kaynaklar, kitaplar ve bildirilerin yer aldığı tespit edilmiştir.

Apak ve diğ. (2016) çalışmalarında Muhasebe ve Finans Tarihi Araştırmaları Dergisi'nde yayınlanan makaleleri bibliyometrik analiz yöntemiyle incelemişlerdir. Çalışmada söz konusu derginin Temmuz 2011 ile Ocak 2016 yılları arası yayınlanmış olduğu 106 makale araştırma kapsamına alınmışır. Çalışma sonucunda en fazla yayın yapan kurumun Marmara Üniversitesi olduğu, yayınlarda en çok atıf yapılan kaynaklar arasında da ilk sırada dergilerin geldiği tespit edilmiştir.

Akgün ve Karataş (2017) çalışmalarında Muhasebe ve Denetime Bakış Dergisi' nde 2000-2016 arasında yayınlanmış makaleleri incelemişlerdir. Çalışma sonucunda söz konusu dergide en çok Maliyet-Yönetim Muhasebesi ve Denetim alanında çalışmalara yer verildiği tespit edilmiştir.

Şen ve diğ. (2017) çalışmalarında muhasebe araştırmalarında muhasebe eğitiminin yeri ve önemini muhasebe dergileri üzerinde yaptıkları bibliyometrik analiz yöntemiyle araştırmışlardır. Bu bağlamda Türkiye'nin muhasebe çalışmaları konusunda önde gelen 4 dergisi araşıırma kapsamına alınmıştır. Çalışmada 2009 - 2015 yılları arasında yayınlanmış olan makaleler bibliyometrik analiz yöntemiyle analiz edilmiştir. Çalışma sonucunda en fazla yayının MÖDAV dergisinde yer aldığı, en az yayının 2013 yılında yapıldığı, muhasebe eğitimi konusunun incelenen tüm çalışmalar arasında \%6'lık kısmı oluşturduğu ve daha çok Dr. Öğr. Üyesi unvanına sahip yazarlar tarafından yayın yapıldığı tespit edilmiştir.

Gündüz (2018) 2014-2016 yıllarında akademik dergilerde muhasebe alanında yayınlanmış çalışmaları incelmiştir. Çalışmada bibliyometrik analiz yönteminden faydalanılmıştır. Çalışma sonucunda muhasebe alanında yayınlanan 
makalelerin vakıf, dernek ve diğer kuruluşlara ait dergilerde yayınlandığı tespit edilmiştir. Yine çalışmada muhasebe alanında en çok 2014 yılında Mali Çözüm ve Muhasebe Finansman dergilerinde, 2015 ve 2016 yıllarında ise Muhasebe Bilim Dünyası Dergisi'nde yayınlandığı, analiz yılları kapsamında Muhasebe Denetimi, Muhasebe ve Denetim Standartları ve Finansal Muhasebe alanlarında en çok yayınların yapıldığı tespit edilmiştir.

Yeşil ve Akyüz (2018) çalışmalarında muhasebe alanında ulusal doktora tezlerini bibliyometrik olarak incelemişlerdir. Çalışma kapsamında 320 doktora tezi incelenmiştir. Çalışma sonucunda en fazla doktora tezinin Marmara Üniversitesi'ne kayıtlı öğrenciler tarafından hazırlandığı, incelenen doktora tezlerinin \%76'sının Prof. Dr. unvanlı danışmanlar tarafından yürütüldüğ̈̈, sırasıyla tarımsal faaliyetler standardı, faaliyet tabanı maliyetleme ve adli muhasebecilik kavramlarının en fazla çalışılan konular arasında yer aldığı tespit edilmiştir.

Temelli ve Karcıoğlu (2018) çalışmalarında Muhasebe ve Vergi Uygulamaları Dergisi'nde 2010-2017 yılları arası yayınlanmış 123 makaleyi bibliyometrik analiz yöntemiyle incelemişlerdir. Çalışmada söz konusu derginin belirlenen araştırma yılları süresince kaç makale yayınladıkları, yazar başına düşen makale sayısı, en verimli yazar/yazarların tespiti, makalelerin çok yazarlılık durumu, yazarlar arasındaki ilişki durumu, yazarların unvanları, yıllık ortalama makale sayısı, kullanılan yöntemler, yayın dili, kaynakça sayısı, öz atıf durumu, makalelerin Pareto yasasına(20/20) uyma durumları incelenmiştir.

Öztürk ve Yılmaz (2018) çalışmalarında denetim ve adli muhasebe alanındaki çalışmaları bibliyometrik olarak incelemişlerdir. Çalışmada 1960 - 2018 yılları arası Social Sciences Citation Index’te taranan akademik yayınlar VosViewer programı ile analiz edilmiştir. Çalışma sonucunda son yıllarda denetim ve adli muhasebe konularına verilen önemin akademik yayın anlamında artış gösterdiği tespit edilmişsir.

Özbek ve Badem (2018) çalışmalarında Muhasebe ve Vergi Uygulamaları Dergisi'nde 2008-2017 yılları arası yayımlanmış 149 adet makaleyi çeşitli kriterleri dikkate alarak bibliyometrik analiz yöntemiyle incelemişlerdir.

Bozdemir ve Çivi (2019) çalışmalarında standart maliyet konusunda yapılmış olan çalışmaları görsel haritalama tekniğini de kullanarak bibliyometrik açıdan incelemişlerdir. Çalışmada 1975-2017 yılları arası yayınlanmış ve Web of Science veri tabanında yer alan çalışmalar VOSviewer programı yardımı ile analiz edilmiştir. Yapılan analiz sonucunda çalışma kapsamına alınmış olan yayınların ortak yazarlık, birlikte bulunabilirlik, atıf, bibliyografik eşleştirme, ortak atıf bağı güçlü yazarlar, dokümanlar, kaynaklar, üniversiteler ve ülkeler şeklinde bulgularına erişilmiştir.

Dinç ve Cengiz (2019) çalışmalarında Mali Çözüm Dergisi'nde yayınlanan çalışmaları bibliyometrik olarak incelemişlerdir. Çalışmada 2010-2017 yılları arası yayınlanmış 225 makale araştırma kapsamına alınmıştır. Söz konusu makaleler yazar başına düşen makale sayısı, makalelerin yazım dili, atıf ve sayfa sayısı, yazarların çalıştıkları kurumları, cinsiyeti, unvan dağılımları; makalelerde kullanılan yöntemler, veri toplama teknikleri; derginin en verimli yazarları, makalelerin çok yazarlılık durumu açısından incelemişlerdir.

\section{Araştırmanın Önemi ve Amacı}

Sosyal bilimler alanında bibliyometrik analiz yöntemiyle yapılmış olan çalışmalar gün geçtikçe yaygınlaşmaktadır. Çalışmanın literatür araştırması kısmında da görüleceği üzere sosyal bilimler alanının yanı sıra farklı bilim dallarında birçok araştırma da bibliyometrik analiz yöntemi kullanılmışır. Ancak yapılan literatür araştırması sonrasında muhasebe alanında yapılmış olan çalışmaların genelde spesifik dergilerde yayınlanmış çalışmaları incelediği, muhasebe biliminin alt bilim dallarını inceleyen bibliyometrik analiz yöntemiyle yapılmış çalışmaların yok denecek kadar az olduğu tespit edilmiştir. Bu bağlamda çalışmanın yönetim muhasebesi özelinde Türkiye’de hazırlanmış lisansüstü tezleri konu edinmesi açısından önem arz ettiği düşünülmektedir. Söz konusu önem doğrultusunda çalışmanın amacı Türkiye'de yönetim muhasebesi konusunda hazırlanmış olan lisansüstü tezleri belirlenmiş kıstaslar doğrultusunda bibliyometrik analiz yöntemiyle analiz etmektir. Ayrıca yönetim muhasebesi konusunda en çok lisansüstü tezin hangi üniversiteye kayıtlı öğrenciler tarafından hazırlandığı, yıllar itibariyle dağılımı, danışmanlık yapan öğretim üyelerinin unvanları ve tezlerin türüne göre ayırımının belirlenmesi çalışmanın alt amaçlarını oluşturmaktadır. 


\section{Araştırmanın Yöntemi ve Kapsamı}

Çalışmada nitel araştırma yöntemlerinden olan Bibliyometri tekniği kullanılmıştır. Bu bağlamda Yüksek Öğretim Kurulu Başkanlığı (YÖK) Ulusal Tez merkezi sayfasında tarama terimi olarak "Yönetim Muhasebesi”, aranacak alan, izin durumu ve tez türü kısımları ise "Tümü” şeklinde işaretlenerek 2020 Yılı Nisan ayında tarama işlemi gerçekleştirilmiştir. Tarama sonrası 172 adet lisansüstü tezin YÖK Ulusal Tez Merkezine kayıtlı olduğu tespit edilmiştir. Söz konusu tezlerden 9 tanesine yazarın erişime izin vermemesi, tezin çok eski tarihli olmasından dolayı YÖK tez merkezinde elektronik kaydının olmaması gibi sebeplerden ötürü erişim sağlanamamıştır. Böylelikle araştırma kapsamında 163 adet lisansüstü tez incelenmiştir. Söz konusu tezler yıl, üniversite, enstitü, anabilim dalı, lisansüstü düzeyi ve danışman unvanı kriterleri açısından ele alınmıştır.

\section{Araştırmanın Kısıtları}

Yapılan tüm bilimsel araştırmalarda olduğu gibi bu çalışmanın da birtakım kısıtları bulunmaktadır. Öncelikle yapılan çalışma YÖK tez merkezi sayfasında yapılan aramayla ulaşılan çalışmalar üzerinde gerçekleştirilmiştir. Dolayısıyla yazarı tarafından erişim izni verilmeyen ve YÖK tez merkezi veri tabanında yer almayan tezler araştırma kapsamına alınmamıştır. Çalışmada analiz edilen veriler Nisan 2020 tarihi itibariyle ulaşılan veriler üzerinde gerçekleştirilmiştir. Söz konusu tarihten sonra YÖK tez merkezi sistemine yüklenmiş olan çalışmalar araştırma kapsamına alınmamıştır. Yine çalışmada yapılan bibliyometrik analiz belirli kıstaslar doğrultusunda gerçekleştirilmiştir. Farklı araştırmacıların farklı kıstaslarla farklı sonuçlara ulaşabilecekleri unutulmamalıdır.

\section{Bulgular}

Çalışmanın bu kısmında yapılan bibliyometrik analiz sonucunda elde edilen bulgulara yer verilmiştir.

\section{Türkiye'de Yıllar İtibariyle Yönetim Muhasebesi Konusunda Hazırlanmış Tez Sayılarına İlişkin Bulgular}

Çalışma kapsamında ilk ulaşılan bulgu yıllar itibariyle hazırlanmış olan lisansüstü tez sayılarına ilişkindir. Aşağıda Tablo-1'de Türkiye'de Yönetim Muhasebesi konusunda hazırlanmış lisansüstü tez sayılarına ilişkin bilgi yer almaktadır.

\section{Tablo 1: Yıllar İtibariyle Türkiye’de Yönetim Muhasebesi Konusunda Yayınlanmış Lisansüstü Tez Sayısı}

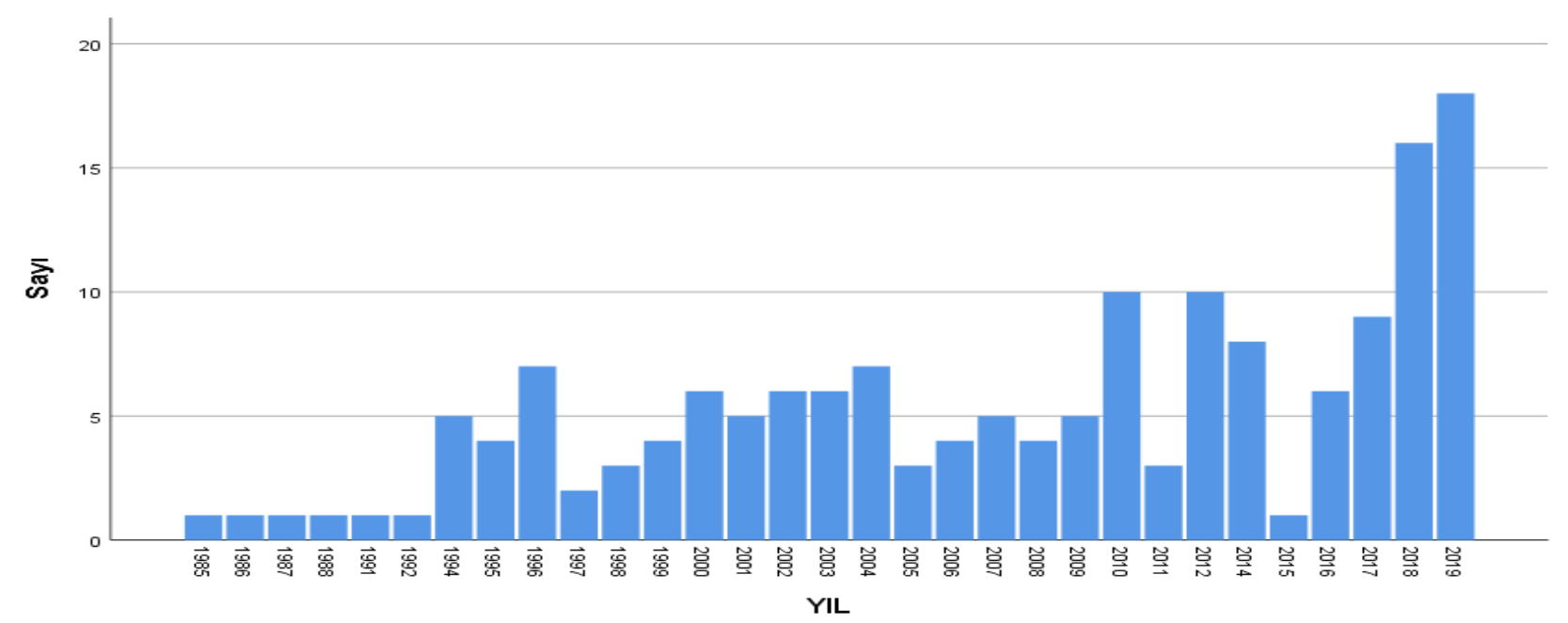

Tablo-1 incelendiğinde son yıllarda yönetim muhasebesi konusunda hazırlanmış lisansüstü tez sayısının artış gösterdiği görülmektedir. 2019 yılında 19 adet tez hazırlanmışken bu sayı 2018 yılında 16 ve 2017 yılında 9 olarak tespit edilmiştir. Türkiye'de yönetim muhasebesi konusunda hiç tezin hazırlanmadığı yıl ise 1993 yılıdır. Ayrıca 1985-1992 yılları arası ve 2015 yılında hazırlanan tez sayısı 1 olarak tespit edilmiştir. 


\section{Tezlerin Lisansüstü Düzeylerine İlişkin Bulgular}

Çalışma kapsamında ulaşılan diğer bir bulgu hazırlanan tezlerin lisansüstü düzeylerine ilişkindir. Aşağıda Grafik-1'de hazırlanan tezlerin lisansüstü düzeylerine göre ayrımı yer almaktadır.

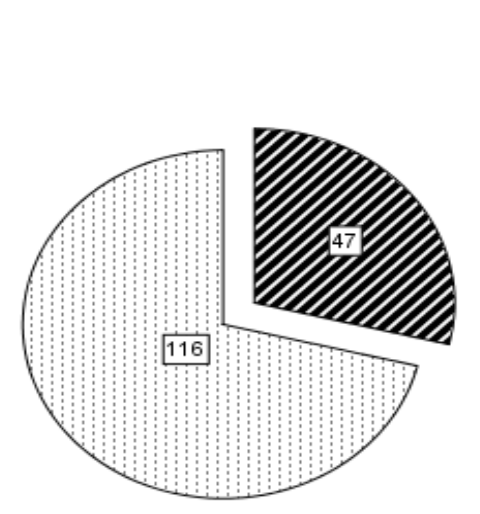

\section{Grafik 1: Hazırlanan Tezlerin Lisansüstü Düzeylerine Göre Ayrımı}

Grafik-1 incelendiğinde yönetim muhasebesi konusunda hazırlanmış olan 163 tezin 47 tanesinin doktora düzeyinde 116 tanesinin ise yüksek lisans düzeyinde olduğu görülmektedir. Doktora düzeyinde hazırlanan tezler tüm tezlerin $\% 28,8^{\prime} l i k$ kısmını oluştururken yüksek lisans düzeyinde hazırlanan tezler \%71,2’lik kısmı oluşturmaktadır.

Çalışma kapsamında incelenmiş olan 163 adet lisansüstü tezin 59 farklı üniversite bünyesinde hazırlandığı tespit edilmiştir. Yönetim muhasebesi konusunda 5 ve üzeri kayıtlı lisansüstü tezi bulunan üniversitelere ait sıralama aşağıda Tablo2'de yer almaktadır.

Tablo 2: Yönetim Muhasebesi Konusunda Hazırlanmış Lisansüstü Tezlerin Üniversitelere Göre Dağılımı

\begin{tabular}{|l|c|}
\hline Üniversite & Lisansüstü Tez Sayısı \\
\hline Marmara Üniversitesi & 19 \\
\hline Sakarya Üniversitesi & 14 \\
\hline İstanbul Üniversitesi & 14 \\
\hline Dokuz Eylül Üniversitesi & 9 \\
\hline Selçuk Üniversitesi & 6 \\
\hline Uludağ Üniversitesi & 5 \\
\hline Muğla Sıtkı Koçman Üniversitesi & 5 \\
\hline Manisa Celal Bayar Üniversitesi & 5 \\
\hline Atatürk Üniversitesi & 5 \\
\hline
\end{tabular}

Tablo-2'de yer alan bilgiler incelendiğinde yönetim muhasebesi konusunda en fazla lisansüstü tezin 19 tezle Marmara Üniversitesi bünyesinde hazırlandığı görülmektedir. Sonrasında 14 tezle İstanbul ve Sakarya Üniversiteleri gelmektedir. Üçüncü sırada 9 tezle Dokuz Eylül Üniversitesi yer alırken Selçuk Üniversitesi bünyesinde yönetim muhasebesi konusunda hazırlanmış 6 adet tez bulunmaktadır. Uludağ, Muğla Sıtkı Koçman, Manisa Celal Bayar ve Atatürk Üniversitesi bünyelerinde ise 5 adet tez hazırlanmıştır. Tablo-2'de yer alan üniversitelerin bünyelerinde hazırlanmış olan lisansüstü tezler türlerine göre de incelenmiştir. Aşağıda Tablo-3'te yönetim muhasebesi konusunda bünyesinde en fazla lisansüstü tez hazırlanmış üniversitelerin tez türlerine göre elde edilmiş verileri yer almaktadır. 
Tablo 3: Bünyesinde En Fazla Lisansüstü Tez Hazırlanmış Üniversitelerin Tez Türlerine Göre Ayrımı

\begin{tabular}{|l|c|c|c|}
\hline \multicolumn{1}{|c|}{ Üniversite } & Yüksek Lisans Tezi & Doktora Tezi & Toplam Tez Sayısı \\
\hline Marmara Üniversitesi & 13 & 6 & 19 \\
\hline Sakarya Üniversitesi & 11 & 3 & 14 \\
\hline İstanbul Üniversitesi & 8 & 6 & 14 \\
\hline Dokuz Eylül Üniversitesi & 7 & 2 & 9 \\
\hline Selçuk Üniversitesi & 3 & 3 & 6 \\
\hline Uludağ Üniversitesi & 2 & 3 & 5 \\
\hline Muğla Sıtkı Koçman Üniversitesi & 2 & 3 & 5 \\
\hline Manisa Celal Bayar Üniversitesi & 5 & 0 & 5 \\
\hline Atatürk Üniversitesi & 3 & 2 & 5 \\
\hline
\end{tabular}

Tablo-3 incelendiğinde yönetim muhasebesi konusunda bünyesinde en fazla yüksek lisans tezinin hazırlandığı üniversitenin 13 tezle Marmara Üniversitesi, yüksek lisans düzeyinde en az tezin ise 2'şer tezle Uludağ ve Muğla Sıtkı Koçman Üniversitelerinin olduğu görülmektedir. Yine bünyesinde doktora düzeyinde en fazla tez 6'şar tezle Marmara ve İstanbul Üniversitelerinde hazırlanmışken bünyesinde doktora tezi düzeyinde hiç tez hazırlanmamış olan üniversite Manisa Celal Bayar Üniversitesidir.

\section{Hazırlanan Tezlerin Enstitülerine İlişkin Bulgular}

Çalışmada ulaşılan diğer bir bulgu tezlerin hazırlandığı enstitülere ilişkindir. Aşağıda Tablo-4'te söz konusu bulguya ilişkin veriler yer almaktadır.

Tablo 4: Hazırlanan Tezlerin Enstitüsüne İlişkin Bulgular

\begin{tabular}{|l|c|c|c|}
\hline \multirow{2}{*}{ Enstitü } & \multicolumn{2}{|c|}{ Tez Türü } & \multirow{2}{*}{ Toplam } \\
\cline { 2 - 4 } & Doktora & Yüksek Lisans & \\
\hline Eğitim Bilimleri Enstitüsü & 0 & 1 & 1 \\
\hline Fen Bilimleri Enstitüsü & 0 & 5 & 2 \\
\hline İşletme Enstitüsü & 0 & 2 & 1 \\
\hline Mühendislik ve Fen Bilimleri Enstitü & 0 & 1 & 2 \\
\hline Sağlık Bilimleri Enstitüsü & 0 & 2 & 152 \\
\hline Sosyal Bilimler Enstitüsü & 47 & 105 & 2 \\
\hline
\end{tabular}

Tablo-4'te yer alan bilgiler incelendiğinde incelenen 163 adet tezden 152 tanesinin (\%93,3) sosyal bilimler enstitülerinde, 5 tane tezin $(\% 3,1)$ fen bilimleri enstitülerinde hazırlandığı işletme ve sağlık bilimleri enstitülerinde 2 'şer tane mühendislik ve fen bilimleri enstitüsü ile eğitim bilimleri enstitüsünde ise l'er tane tezin hazırlandığı görülmektedir. Doktora tezlerinin tamamı sosyal bilimler enstitülerinde hazırlanmışken yüksek lisansa düzeyindeki tezlerin 105 tanesi $(\% 90,51)$ sosyal bilimler enstitülerinde 11 tanesi $(\% 9,41)$ sosyal bilimler enstitüsü dışında kalan enstitüler tarafından hazırlanmıştır. 


\section{Tezlerin Anabilim Dallarına İlişkin Bulgular}

Çalışmada ulaşılan diğer bir sonuç yönetim muhasebesi konusunda hazırlanan lisansüstü tezlerin hazırlandıkları anabilim dallarına ilişkindir. Aşağıda Tablo-5’te söz konusu bulguya ilişkin veriler yer almaktadır.

Tablo 5: Hazırlanan Tezlerin Anabilim Dallarına İlişkin Bulgular

\begin{tabular}{|c|c|c|c|}
\hline Anabilim Dalı & $\begin{array}{l}\text { Doktora } \\
\text { Tezi }\end{array}$ & $\begin{array}{l}\text { Yüksek Lisans } \\
\text { Tezi }\end{array}$ & Toplam \\
\hline Beden Eğitimi ve Spor Anabilim Dalı & 0 & 1 & 1 \\
\hline Endüstri ve Endüstri Mühendisliği & 0 & 2 & 2 \\
\hline Genel İşletmecilik Anabilim Dalı & 0 & 1 & 1 \\
\hline İşletme Anabilim Dalı & 42 & 104 & 144 \\
\hline İşletme Eğitimi Anabilim Dalı & 0 & 1 & 1 \\
\hline Maliye Anabilim Dalı & 0 & 1 & 1 \\
\hline Muhasebe Denetim Anabilim Dalı & 1 & 0 & 1 \\
\hline Sağlık Kurumları Yönetimi Anabilim & 0 & 1 & 1 \\
\hline Sağlık Yönetimi Anabilim Dalı & 0 & 1 & 1 \\
\hline Tekstil ve Tekstil Mühendisliği & 0 & 1 & 1 \\
\hline Turizm İşletmeciliği Anabilim Dalı & 4 & 1 & 5 \\
\hline Yapı Mühendisliği Anabilim Dalı & 0 & 2 & 2 \\
\hline Toplam & 47 & 116 & \\
\hline
\end{tabular}

Tablo-5'te yer alan bilgiler incelendiğinde yönetim muhasebesi konusunda hazırlanmış tezlerin tamamına yakınının işletme anabilim dalında hazırlandığı görülmektedir. Yine Tablo-5'te fen ve sağlık bilimleri alanında yer alan anabilim dallarında da yönetim muhasebesi konusunda tezlerin hazırlandığı görülmektedir. Tablo-5’te en dikkat çekici nokta yönetim muhasebesi konusunda turizm işletmeciliği anabilim dalında 4 adet doktora düzeyinde 1 adet yüksek lisans düzeyinde tezin hazırlanmış olmasıdır. Zira turizm işletmelerinde yönetim muhasebesi konusu oldukça yüksek öneme sahiptir. Bu önemin turizm işletmeciliği anabilim dalında eğitim gören araştırmacılar tarafından da farkına varıldığı görülmektedir.

\section{Hazırlanan Tezlerin Danı̧man Unvanlarına İlişkin Bulgular}

Yönetim muhasebesi konusunda hazırlanmış lisansüstü tezlerin danışman unvanlarına ilişkin bulgular aşağıda Tablo6 da yer almaktadır.

Tablo 6: Hazırlanan Tezlerin Danışman Unvanlarına İlişkin Bulgular

\begin{tabular}{|l|c|c|l|}
\hline Unvan & Doktora Tezi & Yüksek Lisans Tezi & Toplam \\
\hline Dr. Öğr. Üyesi & 4 & 36 & 40 \\
\hline Doç. Dr. & 9 & 30 & 39 \\
\hline Prof. Dr. & 34 & 50 & 84 \\
\hline Toplam & 47 & 116 & 163 \\
\hline
\end{tabular}


Tablo-6' da yer alan bilgiler incelendiğinde Dr. Öğr. Üyesi unvanına sahip danışmanların 40 teze, Doç. Dr. Unvanına sahip danışmanların 39 teze ve Prof. Dr. Unvanına sahip danışmanların 84 teze danışmanlık yaptıkları görülmektedir. Dolayısıyla yönetim muhasebesi konusunda en çok Prof. Dr. unvanlı öğretim üyeleri tez danışmanlığı yapmışlardır. Doktora tezlerine en çok danışmanlık yapan öğretim üyelerinin unvanları sırasıyla Prof. Dr., Doç. Dr. ve Dr. Öğr. Üyesi şeklinde iken yüksek lisans tezlerinde ise sıralama Prof. Dr., Dr. Öğr. Üyesi ve Doç. Dr. şeklinde olmaktadır.

\section{Sonuç}

İşletmelerin geçmiş faaliyet sonuçlarını, gelecekte ortaya çıkması muhtemel olaylara yorumlayarak analiz eden ve sonuçları işletme yönetimi tarafından oldukça stratejik öneme sahip olan yönetim muhasebesi konusu son yıllarda muhasebe alanında yapılan araştırmalar arasında popülerlik kazanmaktadır. Yönetim muhasebesi sadece muhasebe alanında değil fen bilimleri, sağlık bilimleri gibi diğer bilim alanların da araştırma yapanlar tarafından ilgiyle takip edilmektedir. Bu durum yönetim muhasebesinin sadece muhasebe tarafından karar alma süreçlerinde değil işletme yöneticilerinin alacak oldukları stratejik kararlarda sergilemiş olduğu performanstan kaynaklanmaktadır. Bu bağlamda çalışmada yönetim muhasebesi konusunda Türkiye'de hazırlanmış olan lisansüstü tezlerin bibliyometrik olarak incelenmesi amaçlanmıştır. Söz konusu amaç doğrultusunda Nisan 2020 tarihi itibariyle YÖK ulusal tez merkezinde "yönetim muhasebesi" arama ifadesiyle erişime açık ve sisteme kayıtlı olan tüm lisansüstü tezler incelenmiştir. İnceleme yapılırken belirlenen kıstaslar ilgili tezin yayınlandığı yıl, hazırlanan üniversite, enstitü, anabilim dalı, tezin türü ve danışmanın unvanı şeklinde sınırlandırılmıştır.

Yapılan araştırma sonucunda Türkiye'de yönetim muhasebesi konusunda son yıllarda giderek artan sayıda tezin hazırlandığı tespit edilmiştir. Konuyla ilgili olarak ilk tez 1985 yılında hazırlanmışken, 2019 yılında 19 tezle en yüksek sayıya ulaşılmıştır. Yine 1993 yılında yönetim muhasebesi konusunda hazırlanmış lisansüstü tez bulunmamaktadır. Bu durum yönetim muhasebesi konusunun arz ettiği önemin Türkiye'de mevcut araştırmacılar tarafından da fark edildiğinin bir göstergesi olarak yorumlanabilir. Ancak konunun önemi ve kapsamı dikkate alındığında henüz yeterli sayıda tezin hazırlanmadığı da söylenebilir. Yine çalışma sonucunda yönetim muhasebesi konusunda 19 tezle en fazla tezin Marmara Üniversitesi bünyesinde hazırlandığı tespit edilmiştir. Ulaşılan bu sonuçlar Hotamışlı ve Erem (2014), Apak ve diğ. (2016) ve Yeşil ve Akyüz (2018)'ün çalışmalarında ulaştıkları sonuçlarla benzerlik göstermiş ve Marmara Üniversitesi yönetim muhasebesi konusunda da en fazla tezin hazırlandığı üniversite olarak bu çalışmada da tespit edilmiştir. Bu bağlamda özellikle yönetim muhasebesi konusunda lisansüstü tez hazırlamak isteyen araştırmacıların Marmara Üniversitesi bünyesinde alanında uzman öğretim üyeleriyle çalışabilecekleri düşünülmektedir.

Çalışmada yönetim muhasebesi konusunda hazırlanan tezlerin, tez türü olarak en fazla yüksek lisans düzeyinde hazırlandığı tespit edilen diğer bir sonucu oluşturmaktadır. Yüksek lisans tezlerinin hazırlanma amaçları dikkate alındığında bilimsel literatüre yerli araştırmacılar tarafından katkı sağlanabilmesi adına daha çok doktora tezinin hazırlanması gerektiği düşünülmektedir. Yönetim muhasebesi konusunda hazırlanmış olan tezlere en çok Prof. Dr. unvanlı öğretim üyelerinin danışmanlık yaptığı çalışma sonucunda tespit edilen diğer bir sonucu oluşturmaktadır. Bu durum söz konusu öğretim üyelerinin bilimsel bilgi ve tecrübe düzeyleri göz önünde bulundurulduğunda gayet olumlu bir durum olarak yorumlanabilir.

Sosyal bilimler alanında yapılan tüm çalışmalarda olduğu gibi bu çalışmanın da birtakım kısıtları bulunmaktadır. Öncelikle çalışmada Nisan 2020 tarihi itibariyle YÖK ulusal tez merkezi üzerinden yönetim muhasebesi kıstası doğrultusunda ulaşılan tezler incelenmiştir. Yapılan inceleme yukarıda belirtilen sınırlılıklar doğrultusunda gerçekleştirilmiştir. Dolayısıyla farklı araştırmalarda farklı kıstaslarla farklı sonuçlara ulaşılabilecektir. Konuya ilgi duyan araştırmacılar gelecekte yapacak oldukları çalışmalarda muhasebe biliminin alt dallarına yönelik bibliyometrik analizler gerçekleştirebilirler. Ayrıca ulusal ve uluslararası literatürün sınırları çizilmişşekilde geniş çaplı karşılaştırmaları da yapılacak olan araştırmaların konusunu oluşturabilecektir.

\section{Kaynakça}

Akgün, M. ve Karataş, B. (2017). Muhasebe ve Denetime Bakış Dergisinde Yayımlanan Makalelerin Bibliyometrik Analizi (2000-2016). Muhasebe ve Denetime Bakıs, 52, 19-34.

Akkaşoğlu, S., Akyol, C., Ulama, Ş. ve Zengin, B. (2019). Tarım Turizmine Yönelik Hazırlanan Lisansüstü Tezlerin Bibliyometrik Analizi. Journal of Tourism and Gastronomy Studies2, 7(2), 1193-1218. 
Apak, S., Erol, M. ve Öztürk, S. (2016). Muhasebe ve Finans Tarihi Araştırmaları Dergisinde Yayınlanan Makalelerin Bibliyometrik Analizi. Muhasebe ve Finans Tarihi Araştırmaları Dergisi, (11), 111-124.

Armutlu, C. ve Arı, S. G. (2010). Yönetim Modalarının Yüksek Lisans ve Doktora Tezlerine Yansımaları: Bibliyometrik Bir Analiz. ODTÜ Gelişme Dergisi, 37, 23.

Ayaz, N. ve Türkmen, B. M. (2018). Yöresel Yiyecekleri Konu Alan Lisansüstü Tezlerin Bibliyometrik Analizi. Gastroia: Journal of Gastronomy And Travel Research, 2(1), 22-38. doi:10.32958/gastoria.411345

Aydın, B. (2017). Yükseköğretim Kurulu Tez Merkezinde (Yöktez) Yiyecek İçecek İşletmeciliği Alanında Kayıtlı Bulunan Tezlerin Bibliyometrik Analizi. Disiplinlerarası Akademik Turizm Dergisi, 1(2), 23-38. doi:10.31822/jomat.353951

Becerikli, Y. S. (2013). Türkiye’de Sağlık İletişimi Üzerine Yazılan Lisansüstü Tezlerin Bibliyometrik Analizi: Eleştirel Bir Bakış. Ankara Sağllk Hizmetleri Dergisi, 12(2), 25-36. doi:10.1501/ashd_0000000089

Beşel, F. (2017). Türkiye'de Maliye Alanında Yapılmış Lisansüstü Tezlerin Bibliyometrik Analizi (2003-2017). International Journal of Public Finance, 2(1), 27-62. doi:10.30927/ijpf.327823

Bozdemir, E. ve Çivi, F. (2019). Standart Maliyet Yönteminin Görsel Haritalama Tekniğine Göre Bibliyometrik Analizi. Muhasebe ve Finansman Dergisi, 81, 59-84.

Dinç, Y. ve Cengiz, S. (2019). Mali Çözüm Degisinde Yayınlanan Makalelerin Bibliyometrik Analizi. Mali Çözüm Dergisi, 29(155), 33-54.

Gündüz, M. (2018). Türkiye’de 2014-2016 Yılları Arasında Akademik Dergilerde Muhasebe Alanında Yayınlanan Makalelerin Bibliyometrik Analizi. Muhasebe Bilim Dünyası Dergisi, 20(1), 236-257.

Hotamışl1, M. ve Erem, I. (2014). Muhasebe ve Finansman Dergisi'nde Yayınlanan Makalelerin Bibliyometrik Analizi. Muhasebe ve Finansman Dergisi, 63, 1-20.

Huang, C.-Y. ve Ho, Y.-S. (2011). Historical Research On Corporate Governance: A Bibliometric Analysis. African Journal of Business Management, 5(2), 276-284. http://www.academicjournals.org/AJBM adresinden erişildi.

Merigó, J. M. ve Yang, J.-B. (2017). Accounting Research: A Bibliometric Analysis. Australian Accounting Review, 27(1), 71-100. doi:10.1111/auar.12109

Özbek, C. Y. ve Badem, A. C. (2018). Muhasebe Ve Vergi Uygulamaları Dergisinnde Yayımlanmış Makalelerin Bibliyometrik Analizi (2008-2017). Muhasebe ve Vergi Uygulamalar Dergisi, 11(2), 216-247.

Öztürk, S. ve Yılmaz, C. (2018). Denetim ve Adli Muhasebe Alanındaki Çalışmaların Bibliyometrik Analiz Tekniği ile İncelenmesi. Karadeniz2, 39, 173-188.

Şen, K. İ., Hatunoğlu, Z. ve Terzi, S. (2017). Muhasebe Araştırmalarında Muhasebe Eğitiminin Yeri ve Önemi: Muhasebe Dergileri Üzerinde Bibliyometrik Bir Araştırma. Muhasebe Bilim Dünyası Dergisi, 19(1), 247-291.

Temelli, F. ve Karcıoğlu, R. (2018). Muhasebe Ve Vergi Uygulamaları Dergisinde Yayınlanan Makalelerin Bibliyometrik Analizi: 2010-2017 Dönemi. Muhasebe ve Vergi Uygulamalar Dergisi, 11(2), 248-268.

Yeşil, T. ve Akyüz, F. (2018). Muhasebe Alanındaki Ulusal Doktora Tezlerinin Bibliyometrik Analizi. Muhasebe Bilim Dünyası Dergisi, 20(Özel Sayı), 440-472. 